Discussion Paper No. 15-066

\title{
Legal and Illegal Cartels in the European Cement Industry
}

Nikolaus Fink and Stefan Frübing

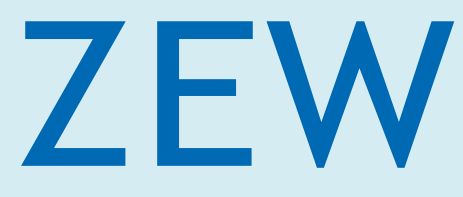

Zentrum für Europäische Wirtschaftsforschung $\mathrm{GmbH}$ Centre for European Economic Research 
Discussion Paper No. 15-066

\title{
Legal and Illegal Cartels in the European Cement Industry
}

\author{
Nikolaus Fink and Stefan Frübing
}

Download this ZEW Discussion Paper from our ftp server:

http://ftp.zew.de/pub/zew-docs/dp/dp15066.pdf

Die Discussion Papers dienen einer möglichst schnellen Verbreitung von neueren Forschungsarbeiten des ZEW. Die Beiträge liegen in alleiniger Verantwortung der Autoren und stellen nicht notwendigerweise die Meinung des ZEW dar.

Discussion Papers are intended to make results of ZEW research promptly available to other economists in order to encourage discussion and suggestions for revisions. The authors are solely responsible for the contents which do not necessarily represent the opinion of the ZEW. 


\title{
Legal and Illegal Cartels in the European Cement Industry ${ }^{1}$
}

\author{
Nikolaus Fink² and Stefan Frübing 3
}

August 2015

\begin{abstract}
Due to being much better documented, legal cartels have recently attracted the interest of many researchers who aim to understand the functioning of illegal cartels in detail. This paper contributes to the question of what we can learn from legal cartels by taking a closer look at the cement industry which has a rich history of both legal and illegal cartels. We undertake a cross-country comparison for Austria, Germany, Poland and Norway, providing narrative evidence for many traits of the cases based on a variety of detailed sources. We identify similarities between legal and illegal cartels in aspects such as monitoring efforts, information exchange, the importance of industry associations and the role of capacities, whereas we also find substantial differences in the allocation of clients, reactions to deviations and pricing schedules.
\end{abstract}

Keywords: cartels, collusion, cement

JEL Classification: L41, L43, L61

The project was financially supported by the research program Strengthening Efficiency and Competitiveness in the European Knowledge Economies (SEEK) launched by the State Government of Baden-Württemberg, Germany. We thank Richard Havell, Kai Hüschelrath, Ulrich Laitenberger and Konrad Stahl for valuable comments and Bastian Sattelberger for excellent research assistance.

$2 \quad$ Researcher, Vienna University of Economics and Business, e-mail: nikolaus.fink@wifo.ac.at

3 Researcher, ZEW Centre for European Economic Research and $\mathrm{MaCCl}$ Mannheim Centre for Competition and Innovation, L 7, 1, 68161 Mannheim, Germany, e-mail: fruebing@zew.de. 


\section{Motivation}

There is broad consensus that explicit agreements on prices, quantities and the allocation of customers between competing firms (so-called hardcore cartels) regularly reduce consumer surplus and social welfare. Most countries have adopted competition laws which generally prohibit this kind of agreements between competing firms. The enforcement of these laws is rarely easy, however, as it is hard to distinguish cartels from tacit collusion, i.e. non-explicit agreements on certain cooperative strategies which have similar consequences as explicit collusion. In some jurisdictions, cartels had been legal for a long time. In some countries, cartels had to register and were subject to regulation or at least some kind of monitoring. Even until today, agreements between competing firms are permitted in certain industries in some jurisdictions, or even promoted and enforced by the government. Export cartels are such a notable example.

In order to detect illegal cartels, it is crucial to understand them. When and under what circumstances are they formed? How are they organized? How are they sustained? How are they reacting to changes in the economic environment? How are they dealing with competitors outside the cartel? What kinds of events can lead to their breakup? Answering these questions is difficult, as illegal cartels are operating secretly and even after their detection little information becomes publicly available.

An interesting approach to get a better comprehension of illegal cartels is to look at legal cartels. Naturally, legal cartels do not have to operate secretly and this can imply certain differences. Nonetheless, there are a number of issues that are applying both to legal and illegal cartels. For instance, there is the need of finding mechanisms to coordinate the firm behavior, to agree on collusive parameters such as prices and quantities and to monitor the behavior of the participants. Additionally, legal as well as illegal cartels need to deal with deviations of cartel members by punishing cartel breakers or agree at least on compensations for deviations. Finally, potential or existing outsiders are a threat for any cartel. The big advantage of legal cartels is, from 
a researcher's point of view, that they are often very well documented. There is a drawback, however, because it is debatable to which extent results taken from legal cartels can be applied for illegal cartels as well.

In this paper, we tackle this question by looking in detail at the cement industry. It is known as a cartel-prone industry and thus there is a rich history of tacit and explicit collusion between companies in many countries and different legal approaches of governments towards this cooperation. Collusion-facilitating factors such as very homogenous and matured products, high entry-barriers in production, repeated interaction, extensive multi-market contact, stable demand and transparency for suppliers as well as low marginal cost are widely spread in the cement sector. Collusive behavior is frequently observed in different macroeconomic and institutional environments around the world. We consider four European cases of cement cartels for which detailed sources are available and provide narrative evidence of the differences and similarities between the two legal and the two illegal cartels which we compare.

The remainder of the paper is structured as follows: In Section 2, we are going to discuss important existing literature on legal cartels and collusion in the cement industry. In Section 3, we will provide a general overview on the cement industries in the countries which we consider in more detail. In Section 4, we are comparing the cartels from those countries with respect to various criteria. Section 5 concludes the paper.

\section{Literature review}

In this section, we will first discuss existing literature on legal cartels in general and then take a look at papers which examine collusion in the cement sector.

The first notable work on legal cartels is Porter's (1983) study of the US railroad cartel that existed from 1880 to 1886 . The cartel, which was analyzed further by Ellison (1994), featured patterns of deviations from collusive prices and subsequent punishment periods and inspired a comprehensive stream of literature dealing with 
punishment schemes that allow the long-term sustainment of collusive outcomes, applying both to legal and illegal cartels.

However, patient firms (depicted by sufficiently high discount factors) are only one prerequisite for successful collusion. For instance, the study of the sugar-refining cartel in the US from 1927 to 1936 by Genesove and Mullin (2001) shows that there are many other issues which determine the success or failure of a cartel. By observing and evaluating notes of weekly meetings of the cartel members, the authors find that some aspects of actual cartel behavior are not explained by the established economic theory.

Further evidence on legal cartels is provided by Hyytinen, Steen and Toivanen (2013), who take data on Finnish legal manufacturing cartels from 1951 to 1990 in order to determine the amount of cartels and how persistent their existence is. By the end of sample, nearly all industries were cartelized. The same data is also used in Hyytinen, Steen and Toivanen (2015), where the authors identify different types of legal cartels. Another empirical study is Fink et al. (2014a) who describe legal cartels in Austria.

Perhaps the most famous work on legal cartels is Röller and Steen (2006), who consider the case of the Norwegian cement cartel, leading us over to the literature on collusion in the cement sector. Whereas we are focusing on organizational aspects of cartels, Röller and Steen concentrate on evaluating the effectiveness of a cartel, finding that the sharing rule of this particular cartel induced overinvestment in capacities. Previously, Steen and Sorgard (1999) had already considered the case explaining why a small country produced so much more cement than it consumed.

Another case which we will also consider, the illegal German cement cartel, is discussed by Hüschelrath and Veith (2011) as well as Hüschelrath, Müller and Veith (2013). Both papers, as well as the manual for estimating a cartel's damage using the example of the German cement case provided in Hüschelrath, Leheyda, Müller and Veith (2012) supply us with some details on the case, although these works focus on a particular issue rather than getting the overall picture of how a cartel operates. Most recently, Harrington et al. (2014) considered the case of the German cement cartel as 
an example of a situation where a discontent cartel member can lead to the breakdown of the cartel.

Finally, Bejger (2011) examined the Polish cement cartel which will also be considered in this study. Whereas our focus is again on the broader picture, Bejger attempts to answer the question whether the cartel could have been detected by looking at industry data, finding that market shares as well as price and supply showed patterns that were distinctive for collusion.

\section{The cement industry and the cases under study}

\subsection{Industry characteristics}

Cement is both a binding material and an input for both mortar and concrete. It is an essential input for the construction sector. When talking about cement, most people refer to standard grey cement, also known as Portland cement. Portland cement is one kind of grey cement which consists almost as a whole of clinker. Although various other types exist, economists commonly consider cement to be an extraordinarily homogeneous product with very little horizontal or vertical differentiation. 4 There is sufficient supply side substitution among different kinds of grey cement as long as clinker is available.

The major part of the demand for cement originates from the construction industry. Cement is mainly used for the production of concrete. Concrete is a low cost input in the construction industry and substitution possibilities are limited. Thus the demand for concrete and the derived demand for cement is largely price inelastic. 5 As demand originates from construction activity, it is highly seasonal, as little construction work is done in the winter. As construction activity mainly follows general economic activity and interest rates, in the medium run cement demand is also cyclical.

$4 \quad$ The other types of cement have a lower share of clinker.

$5 \quad$ Individual firm demand of course depends on price relative to other firms' prices. 
The quality of cement deteriorates over time. Cement attracts moisture and forms to lumps. Thus the storability of cement is limited to a few months. Customers need the right amount of cement, the right quality at the right place in order to keep the construction work running and in order to fulfil the project plan. The need for sophisticated logistics and timely delivery is a central feature for cement distribution.

The production process of cement is matured and standardized all over the world and consists of basically two steps: Clinker production and grinding. Sintering limestone and clay gives clinker, an important intermediary product. This production step is the most costly one, as it requires both capital-intensive furnaces and cost intensive fuels. ${ }^{6}$ Thus, capacity constraints are binding in the short run and it is reasonable to assume that there are also fixed and variable costs of adjusting capacity. 7 In the second step, the clinker is then grinded with calcium sulfate and other minor constituents.

Characteristics of the production technology imply several barriers to entry. Economies of scale are available for both labor and capital inputs. ${ }^{8}$ Building a new cement plant requires substantial investment. 9 For instance, in a sector inquiry by the UK competition authority (Office of Fair Trading 2012), it was assessed that barriers to entry are high in the cement market. First, a new cement plant requires a permission according to the government's planning system. Second, substantial initial investment of probably more than $\mathrm{f} 100$ million is necessary. The Office of Fair Trading also took as evidence that there is a lack of entry observed and only large international firms are active in the market. Hüschelrath et al. (2012) provide a detailed assessment of the barriers to entry in the German cement market. The need of access to limestone resources, the high initial investment, the requirements to obtain government permission and to fulfill environmental and noise restrictions and the high amount of

\footnotetext{
6 According to Siemens (2009), saving $20 \%$ of the energy costs of a cement production plant would be enough to serve 150,000 German households.

$7 \quad$ See Ryan (2011)

$8 \quad$ See Norman (1979), p. 334. McBride (1981) and Rosenbaum (1994) also confirm size advantages in the cement industry.

$9 \quad$ According to Hüschelrath et al. (2012), p. 137, the necessary initial investment can comprise the amount of three or four annual turnovers.
} 
vertical integration exacerbate entry. However, switching costs are considered to be low due to the high product homogeneity and standardization laws. ${ }^{10}$

Shipping costs for cement exhibit large economies of scale. According to d'Aspremont et al. (2000), a lorry can transport only 25 tons of cement up to $200 \mathrm{~km}$, rail transport is most efficient for around 1300 tons and a ship requires 10000 tons. Thus the more tons of cement are bought, the larger is the area within which suppliers compete for a specific buyer. For smaller buyers, the relatively high transportation costs for truck-load amounts imply the possibility of spatial price discrimination. ${ }^{11}$ Transport by ship is significantly cheaper. Therefore regions close to the sea or with a long coast line are more prone to international trade. ${ }^{12}$

Despite the rather local interaction of suppliers and demand, several companies are represented in many different countries, having established a wide network of cement plants. These include Cemex, HeidelbergCement (or short “Heidelberg”), Holcim and Lafarge which are now all operating in many countries including all those we study in more detail later.

As it is difficult to store cement ${ }^{13}$, prices are more or less determined by the need to actually sell the produced output. The question whether differentiation is important depends on the environmental legislation and the geographic structure. As discussed before, cement is considered to be a rather homogeneous good. This view is also supported by the fact that product differentiation is of minor importance from the demand side; from the supply side, products can be more differentiated the more environmental rules incentivize firms to lower the share of clinker per unit of cement.

\footnotetext{
$10 \quad$ Hüschelrath et al. (2012), p. $155 \mathrm{ff}$

${ }_{11} \quad$ In the US and in many other countries, cement producers used basing-point pricing from 1902 to 1948 until the Supreme Court determined in FTC vs. Cement Institute that this was anticompetitive. See Miller and Osborne (2014).

12 As Miller and Osborne (2014) show, average prices at the western coast of the US are much lower compared to within the U.S. Southwest as imports from East Asian countries are possible.

13 See Ryan (2012). - Loose cement can be stored one month, whereas packaged cement can be stored three months until it attracts water and starts to become lumpy.
} 
Additionally, for markets with a lower plant density and/or asymmetric geographic supply and demand centers, cement is spatially differentiated.

\subsection{Cases and sources}

In this study, we are taking a closer look at the cement markets of Austria, Germany, Norway and Poland. We have chosen these countries on the basis of available information, but also in order to include two different situations, namely detected illegal cartels in Germany and Poland and legal cartels in Austria and Norway.

Austria had a legal, registered cement cartel from 1951 to 1995 . We take the cartel agreement from 1980 since it is available and it was made during a period when cartels were registered and prices were regulated.

For Germany, we are considering the cartel case of four regional cartels, named after the four cardinal directions, which existed simultaneously between around 1991 and 2002. The cartel was discovered by the Bundeskartellamt, Germany's competition authority, which lanced an investigation in May 2002 after complaints from cement buyers. Our main source for the German case is the elaborate court decision of the Higher Regional Court of Düsseldorf from 2009, when it confirmed the conviction but reduced the penalties set by the Bundeskartellamt.

In the case of Poland, we are considering the period from 1998 to 2009, for which the Polish Office for Competition and Consumer Protection (OCCP) charged seven firms for forming a cartel. The main source here is the decision of the OCCP.

Finally, we are taking a look at a country with a legal cement cartel of long-term duration. The Norwegian cement industry was cartelized from 1923 to 1968, with the cartel being followed by a period of monopoly after the cartelist's merger in 1968. Our main source for this is the paper by Röller and Steen (2006). 


\section{Cross-country narrative analysis}

Starting from the criteria used by Toivanen and Hytinen (2012), we compiled a list of aspects according to which we compare the cement market situations in the four countries which we take into detailed consideration. We adapted the criteria on the basis of available information and in order to reflect the fact that we do not study only legal cartels but also three countries where cartels were illegal at the time.

\subsection{Legal situation}

The legal status of cartels naturally has an important influence on its behavior. A legal cartel contract may either be enforced in court or include specific fines or compensations to prevent deviations. Illegal cartels have to come up with a different solution for the challenge. Nowadays, cement cartels are illegal in all countries which we consider for this study. However, all four nations experienced a different path before arriving in the rather similar legal situation of today.

In Poland, the socialist system implied that cooperation between producers was fostered. This changed with the transformation to the free market economy after 1991. Several multinational companies entered the Polish cement market and modern competition law was implemented, making cartels illegal.

In Germany, like many other European countries, cartels were legal before and during the Second World War. In the post-war period, a similar competition law as in the United States was imposed by the Western Allies. The German Competition law listed some exceptions where cooperation between firms was allowed, however hardcore cartels were illegal since the 1950s. This of course did not impede the creation of a series of anticompetitive agreements in the cement industry. ${ }^{14}$

A legal cement cartel was formed in Norway in 1923 and it kept operating until 1968, when the cartelists merged to monopoly. From 1932, firms could even be forced to form 
cartels. A formal ban of hardcore cartels was established in 1960, but enforcement only started around $1980 .{ }^{15}$

In Austria, the cartel law from 1951 obliged cartels to register. Price increases had to be submitted to a regulatory body consisting of social partners that represented workers and firms. Registered cartels were common until Austria's accession to the European Union in 1995.

\subsection{Type of agreement}

In general, cement producers have a set possible action variables upon which they can coordinate. Coordination on the quantity to produce is of major importance as excess production can only be exported due to the bad storability of cement and the priceinelastic demand. The quantity can be fixed by assigning quotas or market shares. Other dimensions of coordination can obviously be the price (including pricing schemes, which will be explained in a later section), but also more complicated matters like capacity investment or product design.

In Austria, the cement cartel agreed on quotas for each member, prices were centrally fixed based on an average cost basis of the whole cartel. Minimizing freight costs was another reason to form a cartel.

In Norway, the cartelists agreed that every firm receives a market share according to its capacity. Prices were set by a common sales office. Capacity planning was not part of the agreement. As the market share was based on the capacity, firms had incentives to excessively extend their capacity. Therefore, collaboration was further increased over time, for instance with regard to packaging, which was standardized in 1957. Consequently, a 1962 agreement had the goal of optimizing the whole industry's production and distribution system. ${ }^{16}$

\footnotetext{
15 See Sorgard (2007)

16 See Röller and Steen (2006), p.327
} 
The Polish cartelists agreed on fixing prices and keeping market shares according to historical shares. In order to prevent deviations, fixing of other sale conditions was implemented over the course of the cartel duration as well. ${ }^{17}$

In Germany, four different regional cartels existed between 1991 and 2002. In all of them, the companies agreed on quantities and market shares. Joint pricing was not directly part of the agreement. In the Northern region, there were also agreements concerning which firm was allowed to deliver into which districts. In the Eastern region, the allocation of clients was coordinated. There were also some meetings in which supraregional issues were discussed. ${ }^{18}$

Consistent with the expectation all cartels under study aimed at fixing the produced quantity. For both legal cartels it can also be observed that pricing was also centrally coordinated, whereas this is ambiguous for the two illegal cartels.

\subsection{Allocation of clients}

Whereas it may be obvious how to fix quantities, it might not be easy to achieve that every firm gets the agreed share of the pie. With imports absent, it may be possible that if the forecast of the demanded quantity is rather good, on average every firm can sell what it produces. This comes potentially, however, at the cost of inefficient delivery. Therefore a mechanism for the allocation of clients seems reasonable for every cartel. "Keeping anything as it is" might be an easy option. Whether freezing the past allocation of clients is the most efficient mechanism for the cartel cannot be investigated further in this paper. However, it seems reasonable that under competition clients are also somehow assigned by proximity, as nearer plants have a cost advantage in delivery. Thus keeping the historic allocation could also be explained by competition and efficient distribution.

${ }_{17}$ Office of Competition and Consumer Protection (2009)

18 OLG Düsseldorf (2009), p. 46 
In Poland, the cartelists did not formally distribute all customers between themselves. However, there was a non-aggression pact, an agreement not to entice each other's "historical" customers. When asked for an offer by a long-time customer of another cartelist, a higher cement price had to be told. If a switch happened nevertheless, the “deprived" long-term supplier often used bilateral talks to discuss a solution. This could be taking over another customer or making a better offer to the customer. ${ }^{19}$ The distribution of production was not efficient, as tax-privileged company Ekocem's production was limited to two thirds of its capacity. ${ }^{20}$

In Austria, the agreement did not explicitly allocate individual clients. However the agreement included quotas and the aim to minimize freight costs. In order to keep relative market shares constant and in order to minimize freight costs, it would be rational for cartel firms to allocate individual customers based on their location as a starting basis to fulfil the agreement. However, the agreement has no explicit territorial allocation of customers.

Whereas there was no full allocation of clients to producers in Germany, at least the northern cartel had the goal of fixing the existing customer bases. As a rule of reason the cartels agreed that there should be talks between the competitors whenever they get approached by a new client. The cartelists sometimes used the method of handing over customers to a competitor as balancing mechanism. ${ }^{21}$

Our sources are not providing detailed information about customer allocation in Norway. However, it is indicated that each firm in the cartel had its own stock of customers, as it is mentioned that one of the companies once delivered a substantial amount to the clients of another company and then compensated the fellow cartelist. ${ }^{22}$

There are no indications that the cartels tried to agree on which clients to supply directly and individually. Instead, there existed some sort of grandfathering of each

\footnotetext{
19 See (276) ff. in Office of Competition and Consumer Protection (2009)

20 See (153) ff. in Office of Competition and Consumer Protection (2009)

$21 \quad$ OLG Düsseldorf (2009), p. 29, 33, 46

$22 \quad$ Steen and Sorgard (1999), p. 1781
} 
members' customers: clients supplied by other cartel members were not supplied, requests of such clients were not met by a competitive offer. It seems that a number of ways of organizing the industry rely on a low churn of customers: In Poland, there was a non-aggression pact. In Austria, quotas and least-freight cost based allocation may have prevented customers from switching their suppliers.

\subsection{Industry associations}

Industry associations can potentially support cartels by facilitating their coordination efforts. This may happen for instance in terms of collecting and distributing information or, in the case of illegal cartels, by offering a legal occasion to meet.

In Poland, all cartelists were organized in the Polish cement association (SPC). As described in the section on monitoring efforts below, it helped sustaining the cartel by collecting and distributing data and information on cement.

In the legal cartel of Norway, all producers were forced members of the common sales office, which coordinated the activities of the companies. ${ }^{23}$ Through it, it was decided which amount of cement was to be exported and how much was sold domestically. The common sales office did also determine domestic quotas according to the capacity of the firms.

In Germany, cement companies are organized in two industry associations. Whereas there is no evidence that one of the associations, which is mainly responsible for negotiating wages with labor unions, was misused for collusion purposes, the Higher Regional Court of Düsseldorf states that the federation of German cement producers, (“BDZ”), played some role in stabilizing the cartel, particular in ensuring market transparency by collecting and distributing data. Moreover, BDZ events provided an opportunity for meetings of the cartelists. ${ }^{24}$

\footnotetext{
23 Information on the Norwegian common sales office is based on Röller/Steen (2006)

$24 \quad$ OLG Düsseldorf (2009), p. 19
} 
In Austria, all cartel members were also members of the association of cement producers ("Verein der österreichischen Zementfabrikanten") that was initally formed in 1894. The association had no formal role in the cement agreement but there was a one-to-one relationship between the members of the cartel and the association -they were the same.

Looking at the evidence from the cases, it seems that industry associations were often involved to at least some degree in both illegal and legal cartel agreements.

\subsection{Monitoring efforts}

In order to sustain a cartel, firms need to prevent each other from cheating on their agreement. Therefore, it is necessary to conduct some monitoring which would detect deviations. This would suggest that a high level of monitoring should be observed for both legal and illegal cartels.

The Polish cement cartelists exchanged a lot of secret information since the founding of the Polish Cement Association (SPC) in 1990, i.e. even before the proven start of the cartel. ${ }^{25}$ The SPC collected information on the monthly production of clinker and cement, domestic sales and export, energy expenditure, investment costs, the number of jobs and many other issues. This information was shared monthly or yearly with all members. After the discovery of the German cement cartel in 2002, the legal status of collecting this information was reevaluated. Subsequently, the task of collecting information was given to a law firm. Whereas aggregated data was published on the internet, individual firm data was distributed by the law firm to the SPC. Moreover, the firms bilaterally exchanged a lot of information. In 2006, the company Cemex Polska Sp. z o.o. admitted to the other cartelists that it had substantially underreported its quantities for five years. 26

\footnotetext{
25 See (116) ff. in Office of Competition and Consumer Protection (2009)
}

26 See (130) ff. in Office of Competition and Consumer Protection (2009) 
For Germany, the cement market during the cartelized period was rather transparent. The cartelists put substantial effort in monitoring each other, especially with respect to monitoring goods stations when imports from the east were expected. ${ }^{27}$ After the German reunification, the market situation was particularly volatile. Thus every plant provided a list of customers and sold quantities which were distributed and used to monitor quotas. These lists were deemed unnecessary in 1995, i.e. several years before the discovery of the cartel and subsequently abandoned.

In Austria, all sales and internal consumption of grey cement had to be notified. The point of measurement was the gate of the manufacturer. Notifications were done on a weekly basis and differentiated with respect to individual plants, different kinds, destination foreign country or destination region within Austria. The chairman collected that information and reported aggregated sales figures and quota fulfillment of each member back to the members. Cartel internal auditing was done by two external and independent auditors. Upon request, cartel members had the duty to provide all information on production, sales and billing to these auditors.

Monitoring in the Norwegian cartel took place within a joint sales company. There, detailed statistics of sales-relevant processes were compiled.

All in all, there was a substantial monitoring effort in both the legal in the illegal cartels we consider.

\subsection{Reactions to deviations}

One of the most interesting issues to observe concerning cartels is how they deal with actual deviations, as options range widely and include for instance price wars, termination of the cartel or renegotiations with the goal of continuing the cartel. Below, we distinguish between minor, possibly unintentional, deviations and somewhat larger, intended deviations. 
In Germany, there was a specific practice in the southern part of the cartel. There were no regular meetings between the three big producers Heidelberg, Schwenk and Dyckerhoff. If the actual market shares differed from the agreement, it was up to the disadvantaged company to start negotiating a settlement of the issue. ${ }^{28}$ This differed from the western regional cartel, where deviations of middle-sized companies seemingly had no serious consequences. ${ }^{29}$ However, there were also instances of nonnegotiated reactions. For instance, the company Holcim, which detected excessive deliveries into the territory to the east of the Weser river, reacted by increasing its deliveries into the region to the west of the Weser river. 30

In Poland, it happened that some firms announced to their fellow cartelists that they would raise prices but then they did not implement these increases. As a reaction, competitors showed evidence that too low prices were used and demanded to follow the increase, arguing that a price war would be a disadvantage for the whole industry. ${ }^{31}$ In general, it was attempted to solve the issue in bilateral negotiation. Remedies included buying cement from the disadvantaged company and handing over some customers, in rare cases also by lowering prices. More important was the rule that companies exceeding the agreed-upon quota had to start in the next price-raising round which increased price. ${ }^{2}$ This staggered price-increase might effectively have transferred customers from members excessing the quota that started to raise prices to members below the quota.

In Norway, side payments played an important role. They were established in order to adjust for sales that violated the proposed market share of a company. 33

In Austria, sales of cement across cartel members were the recommended measure to compensate for deviations from the quota. For larger deviations from the quota, orders

\footnotetext{
$28 \quad$ OLG Düsseldorf (2009), p. 38

29 OLG Düsseldorf (2009), p. 37

30 OLG Düsseldorf (2009), p. 31

$31 \quad$ Office of Competition and Consumer Protection (2009), p. 73

32 Office of Competition and Consumer Protection (2009), p. $74 \mathrm{ff}$

33 Röller and Steen (2006), p.327
} 
with low freight cost were transferred within the cartel. At the end of the year, deviations above $5 \%$ were compensated by a cash payment.

All in all, there was a wide variety of reactions to deviations. Legal cartels tend to make use of the fact that side payments are easily possible. The transfer of customers, possibly by the means a sophisticated price increase scheme as in Poland, was an option for illegal cartels.

\subsection{Capacity}

As noted earlier, capacity plays an important role in the cement industry. In the short run, production possibilities are constrained by the capacity of the plant and adjusting capacity is at least very costly if not unfeasible. Costs per unit are minimized by producing at full capacity whereas low plant utilization is linked with substantially higher costs. 34 In the model of Ryan (2012), capacity is considered as the one aspect by which firms differ, which shows how important capacity constraints are in the industry. 35

In Norway, government permission was necessary for any investment in capacity until about 1950. With the end of shortages due to the aftermath of World War II, this regulation ended and huge investments in capacity followed, as capacity largely influenced each firm's profit due to the configuration of the sharing rule. 36

In Austria, the agreement of 1980 provides no explicit observed rules on capacity increases. However, a participation or investment in an outside firm had to be approved by the plenary meeting with $75 \%$ majority. Entry into the industry was observed in Austria in 1962, 1964 and 1980. The new entrants immediately became members of the cartel. In the case of the last entry in 1980, the new entrant received quotas from each member.

\footnotetext{
$34 \quad$ See Hüschelrath et al. (2012), p. 138

35 See Ryan (2011), p. 3. It should be noted that firms of course differ in other aspects in reality as well, particularly their transportation costs, as these depend on the location of a plant and the respective unloading points.

$36 \quad$ See Röller and Steen (2006), p.325
} 
In Poland, cement production was clearly below the capacity. 37 The German decision also notes difficulties to reach satisfactory plant utilization, particularly in East Germany, where imports from Poland could occur. 38

All in all, excess capacities seem to be normal. This may be industry specific, but excess capacities are also reasonable for a cartel in order to make the threat of punishment more credible and thus prevent deviations.

\subsection{Transparency}

Usually, people have positive associations with transparency in general and market transparency in particular. Full transparency is also a necessary condition for the benchmark of perfect competition. However, in the context of collusion and cartels the positive effect of more transparency is not undisputed, as transparency concerning the activities of competitors makes it easier to detect deviations and thus to sustain collusion.

In Germany, the market conditions during the time of the cartel were rather transparent. This conclusion was reached by the Higher Regional Court of Düsseldorf mainly due to the observation, that unexpected or missing orders of customers were immediately noticed. 39

The Polish decision also states that the cement market was transparent from producer's point of view since cartelist exchanged secret trade information. 40

For Norway, we did not find any direct evidence. However, it seems likely that the common sales office collected all relevant information before optimizing the behavior for the whole industry and also that firms had a good knowledge about their fellow cartelists' capacities and plans.

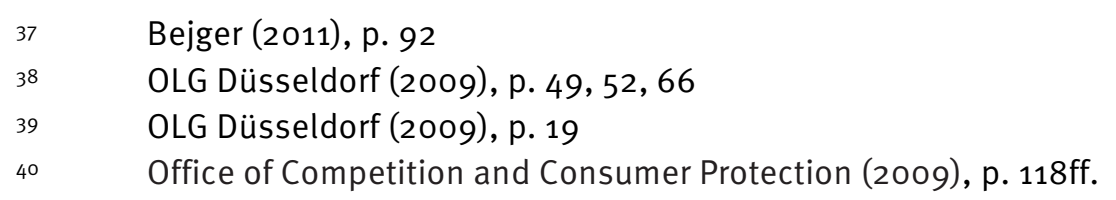


The high level of transparency in Austria was already described in the section on monitoring above. For customers, the registered cartel agreement was publicly available. Overall, we find that transparency was always high for producers which enabled them to quickly notice deviations should they arise. Countervailing transparency for buyers was not prevalent everywhere.

\subsection{Meetings}

Physical gatherings of firm's decision makers are an excellent way of stabilizing a cartel. Whereas legal cartels allow official meetings with the purpose of price or nonprice agreements, evidence of meetings has played an important role in the prosecution of illegal cartels.

The Polish case is a good example of this. The authorities determined that two types of meetings played an important role for the cartel, namely meetings on chief executive level and meetings of trade department heads. Meetings of the latter took place every month between 1998 and 2000, with the main topics being the planning of price increases and the discussion of cases where firms did charge less than the agreed minimum prices. Meetings on chief executive level took place on request and had similar topics, with a tendency for more long-term planning and more important deviations being discussed. ${ }^{41}$

In Germany, meetings were subject to the risk that respective evidence could also be used in court against the cartelists. However, there were regional differences. For instance, in the southern region, there were no regular meetings, whereas in the eastern region, the complexity of the cartel agreement made regular meetings necessary. These were first held in Germany, but later often abroad in order to avoid detection. In this case, data on the cartel's agreement was stored on a computer in 
Switzerland, with access only possible for representatives of two different companies. $4^{2}$

For the legal cartels in Norway and Austria, the number and frequency of meetings is not restricted (beyond the usual cost-benefit assessments of having a further meeting).

\subsection{Entry deterrence and reactions to new entrants}

In general, high entry barriers are an important condition for the success of a cartel. Otherwise, entrants could easily undercut the prices of the cartelists and take many customers away from the cartel, reducing its profits. The cement industry comprises already some entry barriers which were discussed in the third section above. Potential entrants can also be importers. If a new firm enters the cartelized market, an interesting situation arises, as the entrant may constitute a serious threat for the profitable cartel situation.

In Poland, the competition authority concluded that the cartel agreement raised barriers to entry. 43 The only company which entered the market during the cartel took advantage of a special economic zone. In the year 2000 Ekocem Sp. z 0.0. entered the market. This company was able to benefit from being located in a special economic zone, which provided a substantial cost advantage due the exemption from many taxes and fees. The incumbents reacted by agreeing to allow the new firm a production of 400.000 tons. 44 This was implemented by a contract, in which Gorazde Cement S.A. consented to buy this amount annually from Ekocem. The other companies agreed to pass customers with an aggregated demand proportionally to their market share 45 to Gorazde, which then sold these customers the cement produced by Ekocem. In 2003 , Gorazde acquired control of Ekocem. ${ }^{46}$

\footnotetext{
$42 \quad$ OLG Düsseldorf (2009), p. 38 and 46.

$43 \quad$ Office of Competition and Consumer Protection (2009), p. 99

$44 \quad$ The total production amount in 2000 was about 15 million tons.

45 For instance, since Lafarge had a market share of $22.6 \%$, it passed customers with a demand of around 90,400 tons or $22,6 \%$ of 400.000 .

46 Office of Competition and Consumer Protection (2009), p. $41 \mathrm{ff}$.
} 
Entry occurred in Austria in 1962, 1964 and 1980. The last entry had easy access to raw materials and kept the entry secret as long as possible. In Austria, entry into the cartel agreement had to be approved by the existing cartel members.

In Germany, due to the declining demand, there was no entry of other firms in the market. However, imports from other countries were a threat for the cartel, which will be discussed in greater detail below.

\subsection{Pricing schedules}

When it comes to the pricing schedules of legal and illegal cartels, answers to two questions appear especially important. First, how often do cartelists adjust their prices, and second, do they change their prices simultaneously or rather consecutively?

In the legal cartel of Norway, price decisions were centrally taken by the common sales office and thus implemented simultaneously.

In Poland, however, prices were raised consecutively by the firms according to specific agreements. Often, this method was used in order to balance market shares, as companies which sold more than they should according to the plans, were supposed to raise prices earlier in the next round. This proceeding was probably also less suspicious than simultaneous price increases would have been. However, the gap between the price increasing dates was rather small, usually between 1 and 10 days.47

In Germany, the coordination of prices was not an explicit part of the agreement. Cartel firms agreed only that they try to hold prices constant or on a relatively high level. List prices were and are still today announced by so called price letters, and the actual price is then decided by negotiation. As the paper of Hüschelrath et. al. 2012 reveals, there was regularly a substantial difference between the list and the actual price paid.

In Austria, cartel members used a common costing sheet to consider all costs, fixed as well as marginal cost. Price increases were approved by a quasi-regulatory body. Due to 
this regulation, prices were increased for all cement producers within Austria at the same time. The approval of price increases was negotiated on a yearly basis.

In this section, we find several differences, particularly the preference of legal cartels for simultaneous price increases, whereas illegal cartels consider non-simultaneous price increases. The price scheme used by the Polish cartel is rather sophisticated and achieves two goals at the same time, namely deception against a competition authority which might take a closer look at an industry where simultaneous price movements are observed whereas on the other hand, balancing market shares is possible. Common economic models do not suggest this kind of scheme.

\subsection{The role of exports and imports}

Since transport costs are high in comparison to the value of cement, the exports and imports are not a perfect substitute for each customer. This only changes whenever shipping over water is possible, as transportation cost is much lower, or when production cost in a country "nearby" can outweigh the difference in transportation cost. Also, as capacity is fixed in the medium run, trade with other countries is more likely to occur when demand and capacity level differ substantially, as exporting is then a substitute for divesting. Also, imports and exports require a certain infrastructure (such as specific cargo terminals) which cannot be achieved in the short term, but requires investment.

The Polish decision contains data on export and import for the years from 2002 to 2007. The market share of imports ranged between $1.48 \%$ and $5.78 \%$ and not more than $3.78 \%$ of the yearly production were exported. 48

The German cement cartel was regularly challenged by imports, especially from Eastern Europe. Especially at the Eastern border, imports from Poland and the Czech Republic were substantial. Some customers even tried to source cement from Thailand and Indonesia. Those imports triggered a higher demand for information by the cartelists 
and lead them to introduce lists of customers. 49 There is anecdotal evidence that cartel firms tried to stop importing activities by either buying up their cement or simply acquiring the importer themselves.50 It took until the late nineties until exports exceeded imports. This might partly have to do with the fact that German cement producers bought up importing Polish plants thereby reducing importing possibilities. Also the domestic demand dropped significantly due to the downturn of construction activity in East Germany. After the breakdown of the German Cartel it can be observed that Germany has become not only a net exporter, but that almost $20 \%$ of production is shipped outside the country, mostly to the Western neighbors. ${ }^{1}$

In Norway, the cement cartel exported all excess production. The destinations of the exports were mainly non-European countries, a fact which has been explained with fear of retaliation by companies from other European nations who could credibly threat to enter the Norwegian market. 52

For Austria, imports from Germany were never observed on a significant scale. Imports rose when the iron curtain was removed in 1990. Buyer power lead to a significant amount of imports and the approved cartel slowly eroded.

All in all, the role of exports and imports was not that important, which may be a particular result for the cement industry, because transportation costs make up a considerable part of the wholesale price in the cement industry. Alternatively, coexisting cartels across the border - as for Germany and Austria or Germany and Poland for certain periods and thus cartels among cartels offer a different explanation.

\subsection{Overview in tables}

This subchapter contains the findings for all categories in a summary table. Moreover, we provide a table with data on the discussed cartels following the style of the coding

\footnotetext{
49 Fink (2014), p. 15, describes a similar observation for the sugar cartel in Austria-Hungary.

50 OLG Düsseldorf (2009), p. 42-45. The costs for banning imports were then divided by the cartel firms at the national roundtable.

${ }^{51} \quad$ Hüschelrath et al. (2012), p. $145 \mathrm{ff}$

$52 \quad$ Röller, Steen (2006), p.324
} 
protocol by Fink et al. (2014b). Most items in Table 2 are binary and a "Yes" in each category is denoted by a " 1 ". In items regarding market shares, "o" can also mean close to 0 , for instance for the share of imports. 
Table 1: Discussed cement cartels and their characteristics

\begin{tabular}{|c|c|c|c|c|}
\hline & Austria & Germany & Norway & Poland \\
\hline $\begin{array}{l}\text { Considered } \\
\text { time frame }\end{array}$ & $1951-1995$ & 1991-2002 & $1923-1968$ & $1998-2009$ \\
\hline Legal situation & Legal cartel & $\begin{array}{l}\text { Illegal cartel } \\
\text { detected }\end{array}$ & Legal cartel & $\begin{array}{l}\text { Illegal cartel } \\
\text { detected }\end{array}$ \\
\hline Peculiarities & $\begin{array}{l}\text { Prices } \\
\text { increases had } \\
\text { to be } \\
\text { approved by } \\
\text { regulators }\end{array}$ & $\begin{array}{l}\text { Four } \\
\text { simultaneous } \\
\text { regional } \\
\text { cartels }\end{array}$ & $\begin{array}{l}\text { Sharing rule } \\
\text { depending on } \\
\text { capacities }\end{array}$ & $\begin{array}{l}\text { Sophisticated } \\
\text { pricing scheme } \\
\text { for balancing } \\
\text { and deception }\end{array}$ \\
\hline $\begin{array}{l}\text { Type of } \\
\text { agreement }\end{array}$ & $\begin{array}{l}\text { Quotas, } \\
\text { centrally fixed } \\
\text { prices }\end{array}$ & $\begin{array}{l}\text { Quantities and } \\
\text { market shares }\end{array}$ & $\begin{array}{l}\text { Market shares, } \\
\text { centrally fixed } \\
\text { prices }\end{array}$ & $\begin{array}{l}\text { Price fixing, } \\
\text { keeping } \\
\text { historical } \\
\text { market shares }\end{array}$ \\
\hline $\begin{array}{l}\text { Allocation of } \\
\text { clients }\end{array}$ & $\begin{array}{l}\text { Optimization } \\
\text { with respect to } \\
\text { minimized } \\
\text { freight cost }\end{array}$ & $\begin{array}{l}\text { Partly } \\
\text { historical } \\
\text { fixing, but not } \\
\text { sustained }\end{array}$ & $\begin{array}{l}\text { Each company } \\
\text { kept its stock of } \\
\text { customers }\end{array}$ & $\begin{array}{l}\text { Sticking to } \\
\text { historical } \\
\text { distribution }\end{array}$ \\
\hline $\begin{array}{l}\text { Role of } \\
\text { industry } \\
\text { associations }\end{array}$ & No formal role & $\begin{array}{l}\text { Collected and } \\
\text { distributed } \\
\text { data, provided } \\
\text { opportunity for } \\
\text { meetings } \\
\end{array}$ & $\begin{array}{l}\text { Coordination, } \\
\text { organization }\end{array}$ & $\begin{array}{l}\text { Collected and } \\
\text { distributed data } \\
\text { and information }\end{array}$ \\
\hline $\begin{array}{l}\text { Reactions to } \\
\text { deviations }\end{array}$ & $\begin{array}{l}\text { Sales within } \\
\text { cartel or } \\
\text { transfer of } \\
\text { clients }\end{array}$ & $\begin{array}{l}\text { Disadvantaged } \\
\text { party should } \\
\text { start } \\
\text { negotiating }\end{array}$ & Side payments & $\begin{array}{l}\text { Negotiation, } \\
\text { advancement of } \\
\text { next price } \\
\text { increase }\end{array}$ \\
\hline $\begin{array}{l}\text { Role of } \\
\text { capacities }\end{array}$ & $\begin{array}{l}\text { Capacity } \\
\text { investments } \\
\text { had to be } \\
\text { approved by } \\
\text { cartel, entry } \\
\text { added excess } \\
\text { capacity }\end{array}$ & $\begin{array}{l}\text { Overcapacities } \\
\text { existed, thus } \\
\text { strong threat } \\
\text { of retaliation }\end{array}$ & $\begin{array}{l}\text { Strong } \\
\text { overinvestments } \\
\text { as a result of } \\
\text { the sharing rule }\end{array}$ & $\begin{array}{l}\text { Overcapacities } \\
\text { existed when } \\
\text { cartel was } \\
\text { detected }\end{array}$ \\
\hline Transparency & $\begin{array}{l}\text { high at least } \\
\text { for producers }\end{array}$ & high & $\begin{array}{l}\text { probably high } \\
\text { for producers }\end{array}$ & $\begin{array}{l}\text { high for } \\
\text { producers }\end{array}$ \\
\hline Meetings & Not restricted & $\begin{array}{l}\text { Different } \\
\text { frequency } \\
\text { depending on } \\
\text { regions }\end{array}$ & Not restricted & $\begin{array}{l}\text { Frequent, some } \\
\text { regularly, some } \\
\text { on request }\end{array}$ \\
\hline $\begin{array}{l}\text { Pricing } \\
\text { schedules }\end{array}$ & $\begin{array}{l}\text { Simultaneous } \\
\text { prices } \\
\text { increases }\end{array}$ & $\begin{array}{l}\text { Firms kept } \\
\text { some space for } \\
\text { individual } \\
\text { negotiation }\end{array}$ & $\begin{array}{l}\text { Simultaneous } \\
\text { implementation } \\
\text { of price } \\
\text { increases }\end{array}$ & $\begin{array}{l}\text { Consecutive } \\
\text { implementation } \\
\text { of price } \\
\text { increases }\end{array}$ \\
\hline $\begin{array}{l}\text { Role of } \\
\text { exports and } \\
\text { imports }\end{array}$ & $\begin{array}{l}\text { Not important } \\
\text { until } 1990\end{array}$ & $\begin{array}{l}\text { Some } \\
\text { importance of } \\
\text { Eastern } \\
\text { neighbors }\end{array}$ & $\begin{array}{l}\text { Many exports, } \\
\text { but mainly to } \\
\text { South America }\end{array}$ & $\begin{array}{l}\text { Both always } \\
\text { below } 6 \%\end{array}$ \\
\hline
\end{tabular}


Table 2: Data on the discussed legal and illegal European cement cartels

\begin{tabular}{|c|c|c|c|c|}
\hline & Austria & Germany & Norway & Poland \\
\hline Legal & 1 & 0 & 1 & 0 \\
\hline number of firms & 9 & 6 & 2 & 10 \\
\hline start year & 1951 & 1991 & 1923 & 1998 \\
\hline termination year & 1995 & 2002 & 1968 & 2009 \\
\hline entry during cartel & 1 & 0 & 0 & 1 \\
\hline exit during cartel & 0 & 0 & 0 & 0 \\
\hline Merger(s) during cartel & 1 & 1 & 0 & 1 \\
\hline market share of outsiders & 0 & 0 & 0 & 0 \\
\hline market share of imports & 0 & 0 & 0 & 0 \\
\hline termination reason & EU ascension & Detection & merger to monopoly & detection \\
\hline price regulation & 1 & 0 & 0 & 0 \\
\hline market transparent for buyers & 0 & 1 & 0 & 0 \\
\hline market transparent for producers & 1 & 1 & 1 & 1 \\
\hline price fixing & 1 & 0 & 1 & 1 \\
\hline market share fixing/quotas & 1 & 1 & 1 & 1 \\
\hline fixing historical customers & 0 & 1 & 1 & 1 \\
\hline $\begin{array}{l}\text { optimization with respect to } \\
\text { freight costs }\end{array}$ & 1 & 0 & 0 & 0 \\
\hline strong role of industry association & 0 & 1 & 1 & 1 \\
\hline product specialization & 0 & 0 & 0 & 0 \\
\hline capacity restrictions & 1 & 1 & 0 & 1 \\
\hline meetings & 1 & 1 & 1 & 1 \\
\hline information exchange quantities & 1 & 1 & 1 & 1 \\
\hline information exchange prices & 1 & 1 & 1 & 1 \\
\hline $\begin{array}{c}\text { information exchange } \\
\text { exports/imports }\end{array}$ & 1 & 1 & 1 & 1 \\
\hline side-payments & 0 & 0 & 1 & 0 \\
\hline handover of customers & 1 & 1 & 0 & 0 \\
\hline earlier price increases & 0 & 0 & 0 & 1 \\
\hline
\end{tabular}




\section{Conclusion}

Assuming that legal cartels enable learning about illegal cartels, we studied the European cement sector, an industry with a particularly rich history of cartels. We considered two countries with legal cartels, two countries with illegal cartels and compared the narrative evidence of these cases with respect to a variety of aspects.

The legal cement cartels which we considered share several similarities with the described illegal cartels. All four cartels relied on quotas and some sort of price fixing. For all four, customers were not perfectly allocated to individual members, but the churn of customers was kept low. Industry association played a role in information exchange. For all but the Norwegian joint sales company, we observe notification of quantities. In the illegal cartel in Poland, data on inputs to the cement production like energy expenditures and employees were exchanged, too. The legal cartel in Austria relied on external auditors. Next, deviations were met by compensations or side payments in the legal cartels in Austria and Norway. For the illegal cartels, Poland relied on staggered price increases to transfer customers. In Germany, we observe sales outside the agreed-upon territory in order to sanction deviating behavior. None of the cartels was able to effectively restrict capacity. Meetings put illegal cartels at the risk of detection but where necessary to run the illegal cartels. The legal cartel in Austria as well as the illegal cartel in Poland integrated entrants into the cartel. Price setting was transparent for legal cartels. Illegal cartels faced but handled challenges to coordinate due to secret price cutting. We observe imports as a competitive primarily in Germany. Import prevention activities included buying up imported cement or importers themselves. 


\section{References}

d'Aspremont, C., Encaoua, D. and Ponssard, J. (2000). Competition Policy and Game Theory: Reflections Based on the Cement Industry Case. In G. Norman and J. Thisse, Market Structure and Competition Policy: Game Theoretical Approaches (pp. 9-30), Cambridge: Cambridge University Press.

Bejger, S. (2011). Polish cement industry cartel - preliminary examination of collusion existence. Business and Economic Horizons, 4(1), 88-107.

Ellison, G. (1994). Theories of cartel stability and the joint executive committee. RAND Journal of Economics, 25, 37-57.

Fink, N. (2014). The sugar cartel in Austria-Hungary before 1914. Working paper. http://webmeets.com/files/papers/EARIE/2014/469/fink_sugar_cartel_austria_hunga ry_aug_2014.pdf. Accessed 31 March 2015.

Fink, N., Schmidt-Dengler, P., Stahl, K. \& Zulehner, C. (2014a). Registered Cartels in Austria - An Overview. ZEW Discussion Paper No. 14-058.

Fink, N., Schmidt-Dengler, P., Stahl, K. \& Zulehner, C. (2014b). Registered Cartels in Austria - Coding Protocol. ZEW Discussion Paper No. 14-057.

Friederiszick, H. \& Röller, L. (2010). Quantification of harm in damages actions for antitrust infringements: Insights from German cartel cases. Journal of Competition Law \& Economics, 6(3), 595-618.

Genesove, D. and Mullin, W. (2001). Rules, Communication, and Collusion: Narrative Evidence from the Sugar Institute Case, The American Economic Review, 91(3), 379-98. 
Genesove, D, Persson, L., Steen, F., Schmidt-Dengler, P., Stahl, K., Toivanen,O., Zulehner, C. \& Hyytinen, A. (2014). Registered Cartels: An International Comparison, ZEW Discussion Paper No. 14-059.

Harrington, J., Hüschelrath, K., Laitenberger, U. and Smuda, F. (2014). The Discontent Cartel Member and Cartel Collapse: The Case of the German Cement Cartel, ZEW Discussion Paper No. 14-084.

Hüschelrath, K. and Veith, T. (2011). The Impact of Cartelization on Pricing Dynamics, ZEW Discussion Paper No. 11-067.

Hüschelrath, K., Müller, K. and Veith, T. (2013). Concrete Shoes for Competition: The Effect of the German Cement Cartel on Market Price, Journal of Competition Law and Economics 9 (1), 97-123.

Hüschelrath, K., Leheyda, N., Müller, K. \& Veith, T. (2012). Schadensermittlung und Schadensersatz bei Hardcore-Kartellen - Ökonomische Methoden und rechtlicher Rahmen, ZEW Wirtschaftsanalysen, Bd. 102, Baden-Baden.

Hyytinen, A., Steen, F. \& Toivanen, O. (2015). Cartels Uncovered. Working Paper. http://feb.kuleuven.be/public/N10076/Hyytinen_Steen_Toivanen_2015_01_16.pdf. Accessed 18 March 2015.

Hyytinen, A., Steen, F. \& Toivanen, O. (2013): Anatomy of cartel contracts. Working Paper. https://lirias.kuleuven.be/bitstream/123456789/425079/1/MSI_1313.pdf. Accessed 18 March 2015. 
Jans, I. \& Rosenbaum, D. (1996). Multimarket contact and pricing: Evidence from the U.S. cement industry. International Journal of Industrial Organization, 15, 391-412.

McBride, M. (1981). The Nature and Source of Economies of Scale in Cement Production, Southern Economic Journal, 48, 105-115.

Norman, G. (1979). Economies of Scale in the Cement Industry. Journal of Industrial Economics, 1979, 27(4), 317-337.

Office of Competition and Consumer Protection (2009). Decision DOK-7/og of the Polish competition authority regarding the Polish cement cartel.

Office of Fair Trading (2012). Aggregates - The OFT's reason for making a market investigation reference to the Competition Commission. Resource document. http://webarchive.nationalarchives.gov.uk/20140402142426/http://www.oft.gov.uk/s hared_oft/market-studies/oft1358ref.pdf. Accessed 18 March 2015.

OLG Düsseldorf (2009). Court decision Vl-2a Kart 2 -6/o8 of the Higher Regional Court Düsseldorf regarding the German cement cartel.

Röller, L. \& Steen, L. (2006). On the Workings of a Cartel: Evidence from the Norwegian Cement Industry. The American Economic Review, 96(1), 321-338.

Rosenbaum, D. (1994). Efficiency v. Collusion: Evidence Cast in Cement. Review of Industrial Organisation, 9, 379-392.

Ryan, S. (2012). The costs of environmental regulation in a concentrated industry, Econometrica ,Volume 80, Issue 3, p. 1019-1061. 
Siemens (2009). Wie wird Zementherstellung energieeffizient und umweltfreundlich? http://www.industry.siemens.com/datapool/industry/industrysolutions/cement/de/Z ementherstellung-de.pdf. Accessed 18 March 2015.

Sorgard, L. (2007). Cartel Investigations in Norway. Resource document. http://www.konkurransetilsynet.no/iKnowBase/Content/425749/070222_LARS_SORG ARD.PDF.

Steen, F. \& Sørgard, L. (1999). Semicollusion in the Norwegian cement market. European Economic Review, 43(9), 1775-1796. 